Research Journal of Medical Sciences 5 (3): 155-160, 2011

ISSN: $1815-9346$

(C) Medwell Journals, 2011

\title{
Humans Biting Themselves or Others: Nine Cases in European Painting (15-19th Century)
}

\author{
${ }^{1}$ C. Stavrianos, ${ }^{1}$ N. Petalotis, ${ }^{1} \mathrm{O}$. Pantelidou, ${ }^{2} \mathrm{C}$. Papadopoulos, \\ ${ }^{1} \mathrm{~A}$. Pantazis and ${ }^{1} \mathrm{~L}$. Grigoropoulos \\ ${ }^{1}$ Department of Endodontology (Forensic Odontology), School of Dentistry, \\ Aristotle University, Thessaloniki, Greece \\ ${ }^{2}$ Department of Forensic Sciences (Forensic Odontology), University of Glamorgan, Wales, U.K
}

\begin{abstract}
Human beings biting themselves or other humans is something relatively common in Forensics. On the contrary is a very rare subject in Art. The aim of this study is to show nine cases in European painting where this action is depicted. They include frescoes, paintings on wood using tempera and oil colours on canvas, one engraving and two icons. Chronologically they span from 15-19th century. Four of them depict scenes from the Last Judgement of Christ, three of them are inspired from Dante's Inferno as described in the Divine Comedy and the last two are marginal scenes of icons showing the life of St. Andrew the Apostle. Although, these paintings are not the only ones about this subject they are good examples. A thorough research in sculpture and minor arts may yield other examples.
\end{abstract}

Key words: Forensic Odontology, human bite, self biting, European painting, Last Judgement, Divine Comedy, St. Andrew

\section{INTRODUCTION}

The trauma caused on the skin from the contact of the teeth with or without the contribution of the soft oral tissues (lips, tongue) is defined as a bite mark. They can be caused either by humans or by animals and are usually found in two kinds of cases: crimes and homicides with and without sexual activity and child abuse. Bite marks can be found on both victims and assaulters. In mortal combat situations such as the violence associated with life and death struggles between assailants and victims, the teeth are often used as a weapon. Indeed, using the teeth to inflict serious injury on an attacker may be the only available defensive method for a victim. Human bites may also be used to inflict pain and take revenge. Sometimes someone bites him or herself as a self punishment or as a sign of great anguish and despair (Stavrianos and Vasiliades, 2002; Whittaker and MacDonald, 1989; Stavrianos, 2009). The frequency of occurrence of bite injuries at specific locations varies with the type of crime and sex and age of the victim.

Human bites tend to occur on the face with relatively high frequency, second only to that of human bites of the upper extremity. These injuries are commonly associated with aggressive behaviour, most often involving prominent locations of the face such as ears, nose and lips (Stavrianos et al., 2011). Humans are known to have used their dentition as both tools and weapons since the dawn of time. Humans biting themselves or other people are not something uncommon or new in Forensics (Walter, 1984). Bite wounds are one of the most frequent human traumas (ABFO, 2000; Stavrianos and Vasiliades, 2002; Stefanopoulos and Tarantzopoulou, 2005; Stavrianos et al., 2011). On the contrary is a very rare subject in Art.

The aim of this study is to show nine paintings where this action is depicted. They include frescoes, paintings on wood using tempera and oil colours on canvas, one engraving and two icons. They span from 15-19th century and all of them are European works of art.

\section{CASES IN EUROPEAN PAINTING}

The first three they show the Last Judgment. According to christian belief the last Judgement is the second coming of Jesus Christ where He will judge all the people from the beginning of time according to their actions. It is the end of the world. The good people will be granted eternal happiness but the bad, the non repented sinners will be contemned to hell to eternal tortures.

They were painted by Fra Giovanni da Fiesole better known as Fra Angelico, a famous renaissance Florentine painter (1395-1455). He is listed in the Roman Martyrology

Corresponding Author: Stavrianos Christos, Department of Endodontology (Forensic Odontology), School of Dentistry, Aristotle University, Thessaloniki, Greece 
as Beatus Ioannes Faesulanus, cognomento AngelicusBlessed Giovanni of Fiesole, nicknamed Angelico (Beissel, 2007). The 16th century Italian biographer Vasari says of him: But it is impossible to bestow too much praise on this Holy Father who was so humble and modest in all that he did and said and whose pictures were painted with such facility and piety (Ahl, 2008). In 1982 he was beatified by Pope John Paul II and declared patron Saint of Catholic artists.

The first altarpiece was painted circa 1432-1435 using tempera and gold on wood panel. It was painted originally for the Camaldolese convent of Santa Maria delgi Angeli in Florence. It is located at the Museo di San Marco in Florence. San Marco is the monastery where Fra Angelico lived and created many of his masterpieces. On the right side of the panel the condemned sinners are dragged by devils to hell (Fig. 1).

Rich men and women, merchants, monks, soldiers, kings, a cardinal and a bishop are pushed, prodded and hooked in a hurry by unmerciful terrifying devils to the entry of hell. Their deepest sorrow and despair for their future is shown by their movements and facial expressions. Among them we notice a young couple and a bishop biting their hands. Their eyes are half closed and they move towards the gate of hell. There is no mercy and sympathy for no one. Next there can see the interior of hell (Fig. 2).

It is depicted as a cave full of different pits where the sinners are punished in different groups. Four levels are visible with seven divisions corresponding to the seven deadly sins. Eternal darkness, flames, devils and monsters make this eternal torture chamber even worse. In the third level, in the pit at the left men and women are punished for

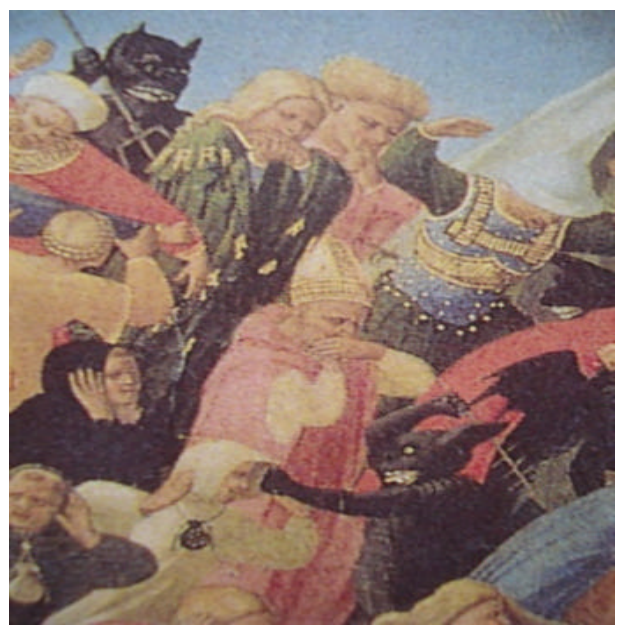

Fig. 1: Fra Angelico. The condemned sinners are dragged to hell, detail, Museo di San Marco, Florence being angry at their life time. Among them we notice a monk and a king. Snakes, flames and a demon make their torture worse. A man and a woman and two men are fighting with each other. The two men, one of them is a monk-tear each other apart with their teeth like fighting animals. Two men and a woman are biting theirs hands. The wound are easily seen, their blood is running but there is no end for their sufferings.

The second altarpiece was painted circa 1435-1440. It belongs to the Gemaldegalerie in Berlin since 1884. On the right side among the other condemned a monk guilty for avarice is biting his palm. Next to him a young couple perhaps man and wife-tear each other apart with their teeth like fighting dogs and rip out each other's hair (Fig. 3).

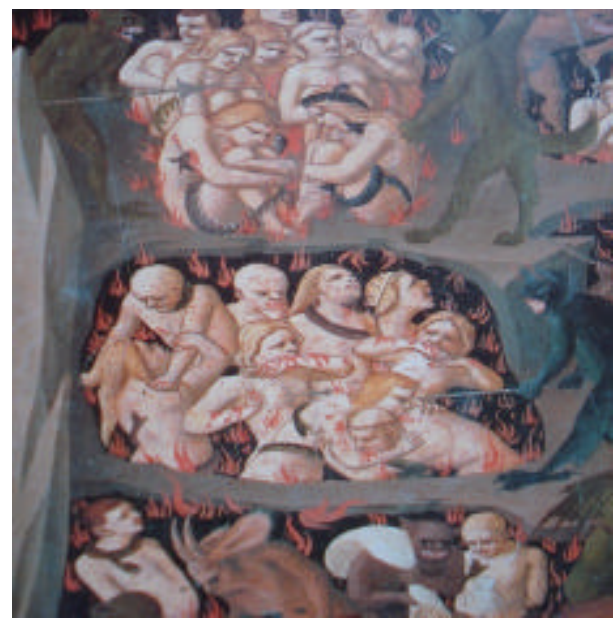

Fig. 2: Fra Angelico. Punishment of sinners in a Hell's pit, detail, Museo di San Marco, Florence

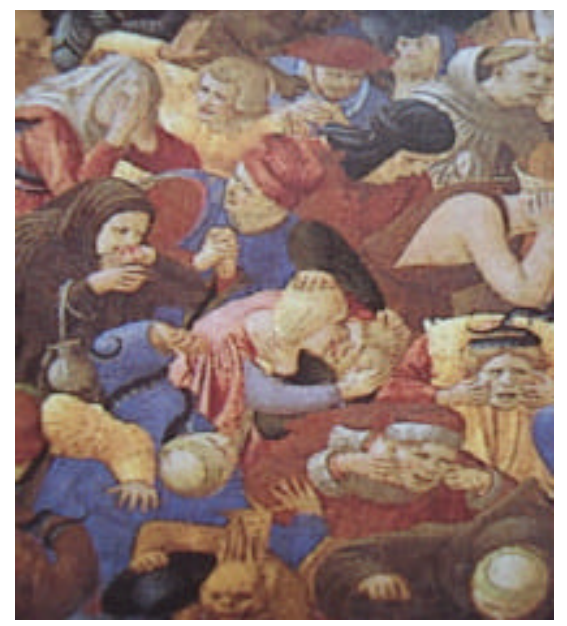

Fig. 3: Fra Angelico. The condemned sinners are dragged to hell, detail, Gemaldegalerie Gallery, Berlin 


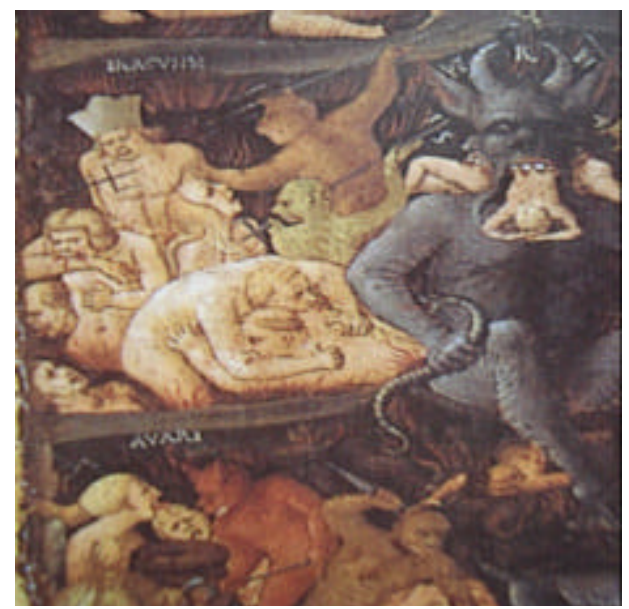

Fig. 4: Fra Angelico. Punishment in a hell's pit, detail, Gemaldegalerie Gallery, Berlin

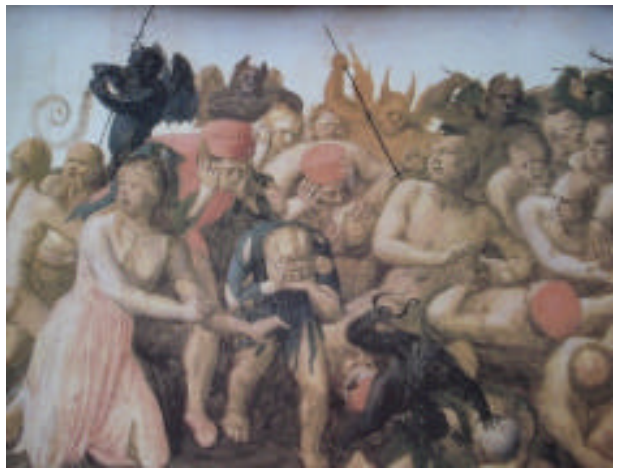

Fig. 5: Fra Angelico. Detail from the Last Judgment. Part of the Armadio degli argenti, Museo di San Marco, Florence

Again there have a similar depiction of hell (Fig. 4). In a pit among other condemned two men-perhaps monks are biting each other and one man bites his hand. Interesting is the depiction of Satan who devours three sinners.

The third one is not an altarpiece. It is one of 35 paintings originally used as shutters for the holy relic cases in the church of Santissima Annunziata in Florence. It was painted circa 1450 and it is treasured also in the Museo di San Marco in Florence. It depicts again the Last Judgment but in a shorter version due to the smaller dimensions. On the right side again the damned are dragged to hell (Fig. 5). Among them a man and a woman are fighting. The man having a merchant hat is biting perhaps his wife in an attempt to punish her for his fate. Just below them a man is biting his palm. There is no depiction of hell.

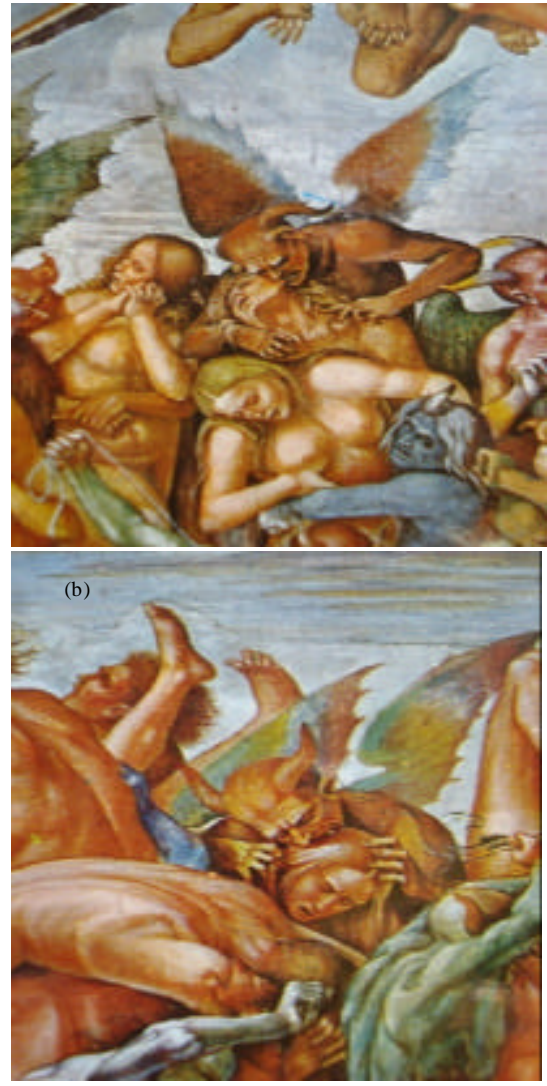

Fig. 6: Luca Signorelli. A demon bites a sinner. San Brizio's chapel, Orvieto, Cathedral

Two other interesting depictions are found in the Cathedral of the Italian city of Orvieto. They are located in San Brizio chapel or capella nuova and were painted by the Italian Renaissance painter Luca Signorelli (c.1445-1523). The show the Last Judgment and scenes from the Revelation and were painted around 1499. In a multifigural composition the condemned are dragged to hell by merciless demons. The demons have human faces and characteristic horns and ears. The first has grasped a young man and bites his ear and the other bites and in fact fractures the head of another young man (Stavrianos et al., 2011) (Fig. 6a and b).

The next painting depicts a scene from the epic poem Divine Comedy, the most famous work of the Italian poet Dante Alighieri (1265-1333). It was painted on canvas by the French painter William-Adolphe Bouguereau (1825-1905) and belongs to a private collection (Fig. 7). In Divine Comedy, Dante describes his trip to Inferno (Hell), Purgatory and Paradise. In Inferno as described in canto VII, verses 110-114 and more specifically in the 5th circle, Dante with his guide, the roman poet Virgil watch the punishment of vengeful people. 


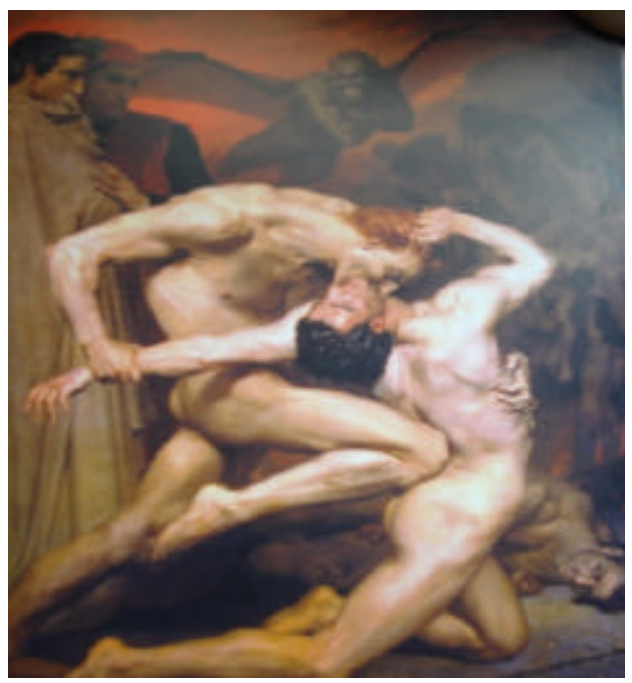

Fig. 7: William-Adolphe Bouguereau. Dante and Virgil in Inferno. Private collection

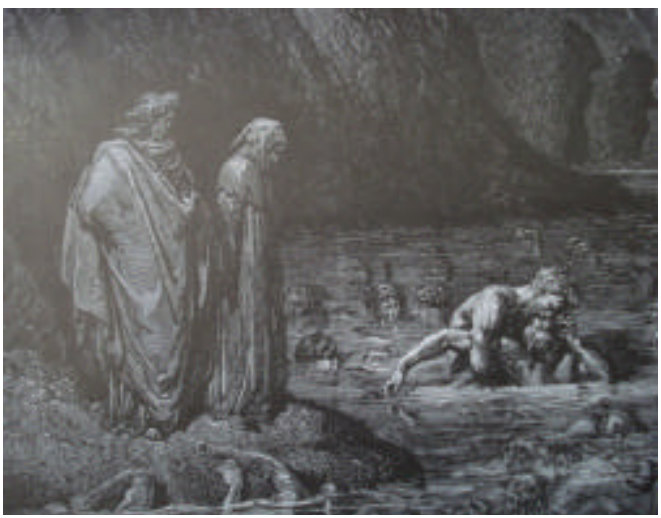

Fig. 8: Gustave Dore. Dante's Inferno. Count Ugolino and Archbishop Ruggieri

In the centre of the painting there is a complex of two naked men fighting in fury. They use as weapon every part of their body. The blond man bites ferociously the neck of his opponent. The muscles of his face contract and transform it to a horrific mask. His eyes have the look of a wild beast. On the left of the painting there can see Virgil and Dante, dressed in red. Worth mentioning is the demon with a characteristic smile of satisfaction.

Divine Comedy inspired also Gustave Dore (1832-1883), perhaps the most famous 19th century European engraver. In 1861 Dore engraved and published Dante's Infernol on his own expenses (Dore and Alighieri, 1976). The present engraving depicts the verses 124-139 of Canto XXXII (Fig. 8).

On the 9th circle of hell there is a frozen icy lake with four different pits. In the second pit are condemned those

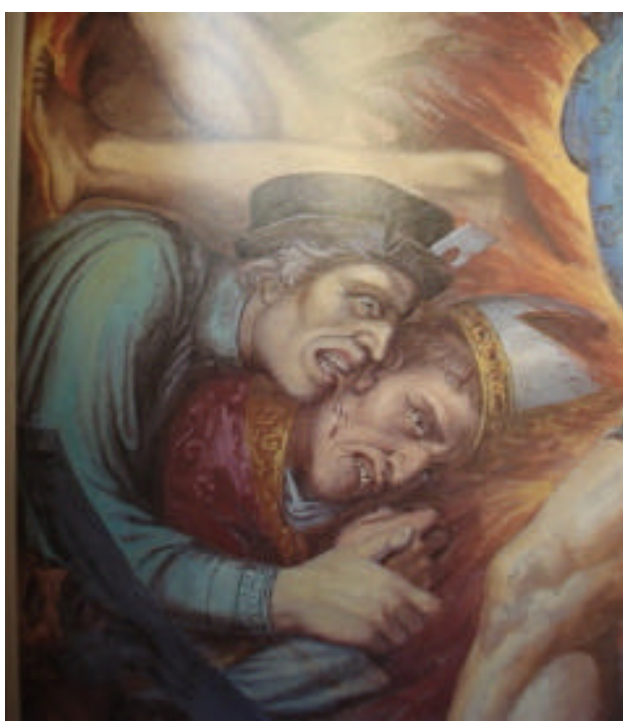

Fig. 9: Dante's Inferno. Count Ugolino and Archbishop Ruggieri. Sala di Dante, villa Massimo, Rome

who betrayed their country and to the third those who betrayed their friends. On the margin of the second pit Ugolino della Gherardesca count of Donoratico is constantly gnawing at Ruggieri's skull and neck of his ex-friend, Ruggieri degli Ubaldini, Archbishop of Pisa located in the third pit. The Archbishop condemned Ugolino, his two sons and two his grandsons to starve to death. In his prison Ugolino before he dies, ate the flesh of his dead children and grand children. On the left Dante and Virgil are watching the terrible scene.

Author saw two shades frozen in a single hole, packed so close, one head hooded the other one; the way the starving devour their bread, the soul above had clenched the other with his teeth where the brain meets the nape (Canto XXXII, lines 124-129).

The same dramatic incident is depicted on the walls of a Roman mansion, villa Massimo. The so called Dante's room (sala di Dante) was frescoed by the Nazarenes painters during 1817-1827. The Nazarenes were a group of German painters who worked mainly in Rome and tried to purify the painting from academic forms and preferred religious and patriotic themes. Among bare rocks Ugolino devours Ruggieri dressed in his vestments (Fig. 9). The expressions of their faces and the blood coming from the wound are worth noting (Friedman et al., 1998).

The seventh painting is a 19th century Greek icon of St. Andrew the Apostle. It is located at the church of St. Andrew in the Greek city of Patra where St. Andrew suffered martyrdom. It was painted by Makarios Galatsanos a 19th century monk icon painter (circa 
1819-1863). He was nephew of the older Makarios and Beniamin's brother, all of them famous icon painters. Their origin is from the village of Galatista in Chalkidiki hence the name Galatsanos. He lived in mountain Athos-Hagion Oros-in Greece. He was one of the most famous icon painters of 19th century in Balkans (Chatzidakis and Drakopoulou, 1997).

According to his Vita (life) St. Andrew the Apostle (1st century A.D.) spread Christianity in many cities. Among them the Black sea coast cities in Asia Minor-Anatolia in Turkey: Heraclea of Pontos-Eregli, Amisos-Samsun, Sinope-Sinop, Trapezous-Trabzon. Sinope was one of the most important cities of the Pontus region. Before him Apostle Mathias preached Christianity in the city but he was imprisoned in order to be killed and later eaten by them like an animal.

When St. Andrew arrived at Sinope he tried to proselytize both Greeks-Pagan worshipers and Jews. When he learned that Apostle Mathias was imprisoned, he set him free miraculously by his prayer. Later when he continued his preaching, it was not accepted by the citizens. They became furious and as a mob arrested him and tried to find the way to kill him. They said If we decapitate him he will not suffer enough if we burn him alive we can't eat him. They decided to tie a rope around the Saints neck and drag him in the streets of the city and when he dies to divide and eat his flesh and so it was done. In the end of the day the saint still alive was thrown to the city prison with his hands tied up. The same happened for other 2 days. He was dragged in the streets of the city; beaten in various ways and stones were thrown at him. Other men were biting his flesh and one using his teeth cut the saint's finger (Pnevmatikakis, 1971).

In the third night Christ appeared to him and miraculously healed him. Even the saint's finger was healed. The next day the people of Sinope were baptized persuaded from these miracles. Later Apostle Peter went to Sinope and met his brother Apostle Andrew. For many centuries two marble thrones were shown where according to the tradition the two Apostles sat (Laggis, 2001).

On the centre of the icon St. Andrew is depicted enthroned blessing with his right hand and holding an open gospel book on his left. On his right side Jesus Christ bless him and on the left an angel gives to the saint a palm leaf and a laurel diadem as a sign of his victory. Around him 13 scenes of his life are depicted. On the upper row the first from the right side shows the People of Sinope torturing the Saint (Fig. 10). The saint is dragged by his four limbs, two men are throwing stones at him and one man holding St. Andrew's left hand cut the Saint's

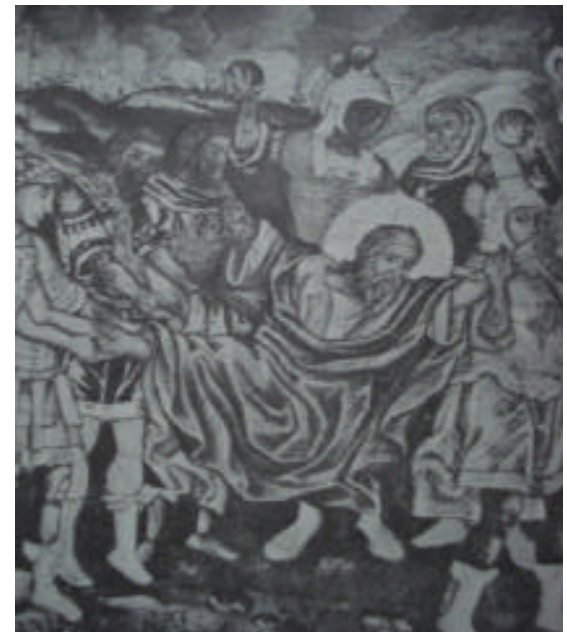

Fig. 10: Makarios from Galatista. The people of Sinope torturing and biting St. Andrew detail, Churh of St. Andrew, Patra

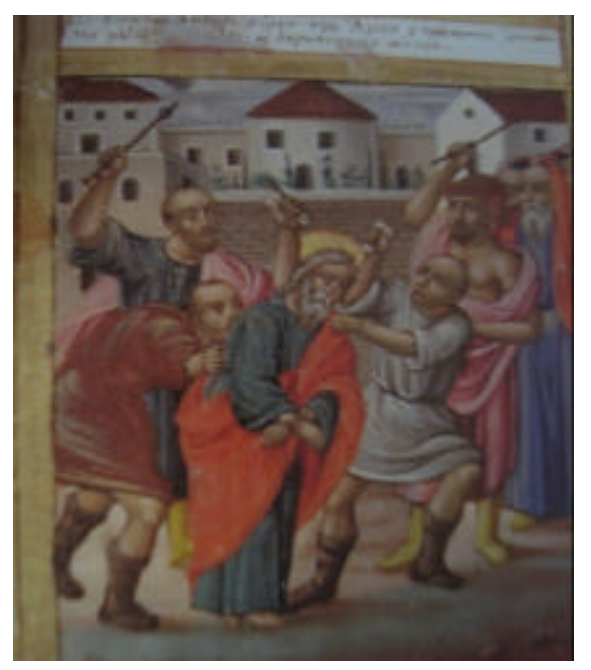

Fig. 11: The sufferings of St. Andrew in Sinope, detail, Church of St. John at Markopoulo, Athens

finger by his teeth. The inscription in Greek say: The people Sinope are dragging the Saint, throwing stones and biting him.

The same scene is depicted in another icon of St. Andrew. It was painted in 1856 by an unknown painter and is located in the church of St. John at Markopoulo region in Attica, Greece. In the center of the icon is the standing figure of St. Andrew surrounded by six scenes of his life and six saints. In one of the marginal scenes St. Andrew is dragged at the streets of Sinope with his hands tighten in front (Fig. 11). Four people surround and torture him. The man on the left is biting the back of the saint. There is a half legible inscription in Greek mentioning that the people of Sinope are biting him. 


\section{CONCLUSION}

Today, Forensic Odontology enjoys an active role in the forensic sciences. Organizations in forensic dentistry have promoted education and research and have set guidelines in the discipline. Bite marks are usually a result of violent interpersonal conflicts induced by child or elder abuse, sexual assault or homicide. A man biting another man or him/her self is not considered something beautiful. It is associated with primitive instincts or extreme grief, pain and despair. That's why it is not strange why it is not depicted often in Art. Although, these paintings are not the only ones about this subject are good examples. A thorough research in sculpture and minor arts may yield other examples.

\section{REFERENCES}

$\mathrm{ABFO}$, 2000. Guidelines and standards: Bitemark Guidelines and Standards. American Board of Forensic Odontology, Colorado Springs.

Ahl, D.C., 2008. Fra Angelico. Phaidon Press, London, ISBN-13: 9780714848303.

Beissel, S., 2007. Fra Angelico. Parkstone Press International, New York, ISBN-13: 978-1859956410.

Chatzidakis, M. and E. Drakopoulou, 1997. Greek painters after the fall of Constantinople (1450-1830). Center Neohellenic Res., 2: 164-165.
Dore, G. and D. Alighieri, 1976. The Dore Illustrations for Dante's Divine Comedy: 136 Plates. Dover Publications, New York, pp: 136.

Friedman, J., M. Caracciolo and F. Venturi, 1998. Inside Rome: Discovering the Classic Interiors of Rome. Phaidon Press, London, ISBN-13: 9780714837628 , pp: 128.

Laggis, M., 2001. The Great Synaxaristis of the Orthodox Church: November. Vol. 11, 7th Edn., Athens Press, Athens, Georgia.

Pnevmatikakis, X., 1971. Andrew, The First-Called Apostle. 5th Edn., Athens Press, Athens, Georgia.

Stavrianos, C. and L. Vasiliades, 2002. Forensic Dentistry. Computers I/O Press, Thessaloniki, pp: 42-45.

Stavrianos, C., 2009. Forensic Dentistry. Vol. 1-2, 1st Edn., University Studio Press, Thessaloniki, pp: 45-98.

Stavrianos, C., L. Vasiliadis, C. Papadopoulos, A. Kokkas, D. Tatsis and E. Samara 2011. Loss of the ear cartilage from a human bite. Res. J. Med. Sci., 5: 20-24.

Stefanopoulos, P.K. and A.D. Tarantzopoulou, 2005. Facial bite wounds: Management update. Int. J. Oral Maxillofacial Surg., 34: 464-472.

Walter, R.A., 1984. An examination of the psychological aspects of bite marks. Am. J. Forensic Med. Pathol., 5: 25-29.

Whittaker, D.K. and D.G. MacDonald, 1989. A Color Atlas of Forensic Dentistry. Wolfe Medical Publications, London. 